\title{
Introduction: narratives and counter-narratives of the International Criminal Court
}

As the world's first permanent international criminal tribunal, the International Criminal Court (ICC or Court) is a pioneering institution. Like many pioneers, the institution has made important achievements and encountered significant challenges. This book provides an overview of the ICC's first two decades, focusing on the dominant narratives and counter-narratives that have emerged about the institution and its work. Our aim is to contribute to a greater understanding of the ICC's actual and potential role in the world by exploring some of the central issues related to its creation, mandate, and operations. To that end, the book addresses topics ranging from the negotiation dynamics surrounding the drafting of the Rome Statute, to the roles of the Office of the Prosecutor, judges, defence and victims, as well as key controversies around peace and justice, selectivity of cases and situations, and gender-sensitivity.

The book's first part describes and analyses the process of creating the ICC. In Chapter 1, William Schabas provides a history of the Court's genesis, and explains the intricate procedures employed in the negotiations of the Statute. Schabas' chapter describes the major players who contributed to the Court's creation and explores some of the challenges they had to overcome. He highlights the controversial role of the US, and the important parts that non-governmental organizations and academics played in the process. Schabas concludes by describing how the intense final days of the Rome Conference yielded the Statute that was ultimately adopted, and observes that the Conference was 'an extraordinary exercise in international law-making'.

In Chapter 2, Frédéric Mégret analyses the Rome Conference negotiations with a view to unearthing retrospective lessons. The chapter considers the negotiations through four lenses: the 'encounter between a particular constellation of actors', the format of an international diplomatic conference, the dynamics within the negotiations, and the cross-cutting issues the Rome Conference was tasked with resolving. In exploring each of these themes, Mégret provides innovative insights. For instance, his assessment of the negotiation dynamics reveals a gap between actors at the negotiation table who had a specific idea of the ICC as a permanent, potentially universal body disconnected from global power politics, and those who did not support any sort of ICC at all. The differing positionality of the actors influenced how much law, and how much politics, shaped the final outcome. Mégret concludes that the Rome Conference was, in a sense, transformative: a place where 'political interest is formed through dialogue and persuasion and the sheer experience of seeing one's position constantly refracted against a broader fractious background'.

The second part of the book examines narratives and counter-narratives regarding the interpretation and application of the Rome Statute. The chapters describe and critique various parts of the Statute, analysing the Court's jurisprudence and the relevant scholarship. In Chapter 3, Saira Mohamed describes and problematizes the dominant narrative of contestation surrounding the designation of the four crimes in the Statute. The chapter considers various ways of framing the debate about which crimes should be included in the ICC's jurisdiction, and argues that the choices made in Rome both contributed to the creation of a hierarchy of 
international crimes, and reflect a desire to reshape the world order around the protection of human lives.

Next, in Chapter 4, Alexander Greenawalt addresses the complexities of the Rome Statute's admissibility regime, which he identifies as 'one of the most fundamental and mysterious aspects of the ICC's structure'. As Greenawalt explains, admissibility is central to defining the ICC's mission and yet is remarkably undertheorized both in terms of the content of the values and norms at stake, and in regard to the roles of prosecutorial and judicial discretion, as well as Security Council authority, in implementing the concept of admissibility. The chapter explores open questions about the nature of the ICC's admissibility regime through an analysis of the Court's experiences with admissibility to date.

In Chapter 5, Leila Sadat examines the Statute's provisions concerning the accountability of heads of state and other government officials. Sadat focuses on narratives and counter-narratives surrounding Article 27 of the Rome Statute (on the irrelevance of official capacity and non-applicability of immunities) and Article 98 (on pre-existing legal obligations of a country asked to surrender a diplomat) of the Rome Statute. She argues that the controversies surrounding these articles have their origin 'in a political, not legal, question'. Sadat concludes that current efforts to rewrite the meaning of Article 27 seek to change existing customary international law and impose, post facto, a new interpretive gloss on Article 27, fundamentally changing its meaning and scope.

Mark Drumbl, in Chapter 6, explores how the ICC has interpreted and applied the provisions of the Statute pertaining to punishment. He highlights the Court's use of sentences to mark gradations in responsibility and assesses its efforts to attain penological goals. After a thorough review of the ICC's sentencing practice, Drumbl identifies unresolved challenges related to penological objectives and to life after serving ICC sentences. He concludes with some observations about how the ICC's activities are expanding the penology of international crimes.

Chapter 7, by Rod Rastan, addresses the critical issue of state compliance. He questions how, and indeed whether, the ICC can function without state cooperation. Rastan explains the significant extent to which the ICC's operations depend on state assistance with such critical tasks as securing evidence and ensuring witness cooperation. He notes the paradox of this reliance for an institution that is mandated to 'complement' national systems that are unwilling or unable to adjudicate serious international crimes. The chapter assesses the measures the Court can take to address non-compliance through an in-depth examination of international court practice. Rastan concludes that, unless such measures can be implemented successfully, the ICC will be unable to contribute meaningfully to ending impunity in many situations.

The book's third part examines how major players at the ICC help to shape the Court's role in the global legal order. The chapters discuss narratives and counter-narratives related to several aspects of the ICC in action. In Chapter 8, Mark Kersten tackles one of the most controversial aspects of the ICC's operations: how it decides which situations and cases to investigate and prosecute. Kersten advances an innovative theory of 'prosecutorial opportunism' whereby such decisions represent 'an expression of a negotiation between the institutional interests of the Court and the political interests of the actors, particularly states, on which the Court depends'. Using a series of examples, he shows how states can manipulate prosecutorial opportunism in pursuit of their own interests, in particular their interest in avoiding prosecution of government actors. He concludes that, to elude such manipulation, the ICC should ensure its selection strategies are not overly predictable. 
Sara Wharton, in Chapter 9, considers whether the ICC's judiciary, registry, and defence counsel adequately protect defendants' rights. She begins by examining the rights of the accused as set forth in the Rome Statute and related documents, and assessing how court actors seek to realize those rights. In particular, she discusses recurring narratives on the gaps in equality of arms between the prosecution, defence and victim representatives. Wharton argues that although in principle, the relevant instruments provide for equality of arms, the Court's practice does not live up to this ideal. She recommends reforms to ensure that 'these rights are fully guaranteed in practice and not only on paper'.

In Chapter 10, Jennifer Trahan examines the theory and reality of the role of the Assembly of States Parties (ASP). She begins with a description of how the ASP was designed to function, then turns to an analysis of how it has actually been functioning, focusing on certain core activities, including election of judges, setting the ICC's budget, agreeing on Rome Statute amendments, and negotiating the annual 'omnibus resolution'. The chapter concludes with consideration of future challenges for the ASP, including: ensuring it does not interfere with the ICC's independence; guaranteeing the Court has a sufficient budget to perform its work; more effectively addressing the problem of State Party non-cooperation (particularly as to outstanding arrest warrants); and handling other 'push back' against the work of the ICC.

The last chapter in this part, Chapter 11 by Rebecca Hamilton, examines the roles that the Security Council and African Union (AU) have played in determining the ICC's ability to fulfil its mandate. Hamilton focuses on the 'anti-Africa' narrative of the Court's work that emerged at the AU, on the Security Council's role in that narrative, and on the responsive 'a-political court' counter-narrative at the Court. The chapter problematizes both narratives, arguing that they fail to address the real substantive challenges the Court faces. These include the repercussions of initially pursuing an all-Africa docket and of the Security's Council's failure adequately to support the Court's work after referring situations.

The final part of the book addresses some of the major controversies surrounding the ICC's work. The chapters provide an overview of the main narratives on each issue, and offer insights into the extent to which they affect the Court's success. This part begins, in Chapter 12, with an examination by Yvonne Dutton of the recurrent theme in international criminal justice of whether, and to what extent, peace and justice are in tension. The chapter situates the debate in historical context and sets forth the narratives on each side, focusing on how the debate has played out in discussions about the ICC. Employing case studies, Dutton shows that the ICC's decisions to prosecute defendants in situations of ongoing conflict have made the debate about whether international prosecution has a positive or negative effect on peace more complex.

Next, in Chapter 13, Asad Kiyani examines the controversies surrounding ICC selection decisions. The chapter considers the intense public debate around whether the ICC is a 'selective' court, and whether that selectivity matters for the Court's legitimacy. One narrative is that 'the Court is clearly selective and thus has lost or diminished credibility as a judicial body'. A counter-narrative is that 'selectivity is an ordinary part of criminal justice systems', and so 'selectivity ... may even indicate that the Court is successful and legitimate'. Kiyani disputes both perspectives as reductive and misleading. The central focus, in his view, should be on when selectivity is impermissible. Kiyani proposes a new typology, situating the ICC within a multi-institutional and multi-jurisdictional context. Using two examples - the geographic distribution of cases, and the differentiation between parties to a conflict or atrocity-he concludes that the main selectivity issues at the ICC arise not because of what happens between 
states, but within states, in particular with the interaction of the ICC with local legal and political actors and institutions.

Chapter 14, by Jonathan O'Donohue, argues that the ICC has faced significant challenges in complying with its strong human rights foundations. In particular, O'Donohue examines common narratives on unequal access to justice by victims of atrocity or conflict-related crimes, the ICC's deference to unfair national tribunals, fair trial concerns such as inadequate legal aid, and ineffective approaches to the rights of victims and witnesses. These concerns, in his view, have been compounded by ineffective cooperation by ICC States Parties and the restricted budgets approved by the ASP. O'Donohue proposes ways the ICC and its supporters can strengthen its human rights record, including prioritizing human rights compliance.

Louise Chappell and Rosemary Grey detail, in Chapter 15, the contested narratives around sex and gender within the ICC. Chappell and Grey analyse the ways in which feminist actors sought to challenge conventional narratives of the role of gender in conflict during the Court's creation, and the extent to which these narratives have actually changed the practice of the ICC. By considering narratives and counter-narratives around sex and gender of different stakeholder communities engaging with the ICC, they show that the reforms to the dominant narrative sought by feminist actors have changed over time. Initially feminist actors prioritized making sexual violence visible in war narratives. More recently, feminist activism and scholarship has focused instead on seeking deeper explanations of sexual violence during atrocity, and on the linkage of socially constructed gender roles to these considerations. They conclude that the Rome Statute is well-suited as a vehicle for a broad conception of gender violence which encapsulates, but is not limited to, sexual violence.

Margaret deGuzman concludes the book in Chapter 16 with an exploration of narratives about the ICC's mission. She argues that the institution's mission as currently conceived is insufficiently precise to enable the Court to identify values and goals to guide its decisions. The chapter focuses on a particular aspect of the Court's 'mission uncertainty': the lack of clarity about what community or communities the ICC is meant to serve. It presents three narratives about the Court's mission as it relates to target communities, which it labels the 'global', 'local', and 'hybrid' narratives. It then demonstrates how decision-making strategies in key areas could differ depending on which of these missions the Court pursues, and concludes with a plea for additional attention to refining the Court's mission.

Collectively, the chapters of this book present a picture of a Court that can boast important accomplishments in its first two decades, but also faces serious challenges, some of them existential. The Statute's drafters overcame a host of hurdles to create an institution with a strong independent prosecutor, the ability to prosecute crimes committed anywhere in the world-at least with a Security Council referral, and strong human rights foundations. It has the support of the vast majority of the world's states, although not all of the most populous or powerful states, and has many strong backers in global civil society. Nonetheless, serious impediments remain to the Court becoming a strongly effective force for global justice. Among the most important of the Court's challenges, addressed in several chapters of this book, is that of ascertaining an appropriate strategy for selecting situations and cases to prosecute. The Statute provides limited guidance in this regard and many of the Court's selection decisions have proven controversial. They have promoted charges of bias against Africans and in favour of powerful actors, and have fuelled claims about the Court as an improperly politicized institution. Whether or not such charges are deserved, the Court must address and overcome them to be successful. In other areas, such as decisions about how to inflict punishment, adhere 
to human rights values, and promote norms of gender equality, the Court has made positive contributions to the cause of justice and also has more work to do. With an institutional review underway, now is an excellent time for the Court and its supporters to engage in dialogue and develop strategies to address these and other challenges so that it can become a powerful force for global justice.

Margaret M. deGuzman and Valerie Oosterveld 